The Chittagong Univ. J. B. Sci., Vol. 5(1 \&2):113-124, 2010.

\title{
EFFECT OF APPLIED LEAD ON THE GROWTH AND ACCUMULATION OF LEAD IN INDIAN SPINACH IN THREE TEXTURAL GROUPS OF SOILS
}

\author{
M. G. KIBRIA*, K. T. OSMAN, M. ISLAM AND M. J. AHAMMAD \\ Department of Soil Science, University of Chittagong, Chittagong 4331, Bangladesh.
}

\begin{abstract}
Indian spinach (Basella rubra L.) was grown in earthen pots containing soils of three different textures and treated with different levels of lead. The effects of $\mathrm{Pb}$ treatments on growth and uptake of $\mathrm{Pb}$ were investigated. At the highest dose of $\mathrm{Pb}$ ( $50 \mathrm{mg} \mathrm{Pb} \mathrm{kg}^{-1}$ soil) leaf, stem and root dry weight of Indian spinach were reduced by 22-34, 11- 43 and 30-47 \%, respectively from control in clay loam, sandy clay loam and sandy loam soil, respectively. Lead concentration in leaf, stem and root generally increased with increasing rate of $\mathrm{Pb}$ application. The highest $\mathrm{Pb}$ concentrations in leaf, stem and root were obtained at $50 \mathrm{mg} \mathrm{Pb} \mathrm{kg}{ }^{-1}$ soil treatment and the values were in the ranges from 49.28 to $65.40,57.72$ to 77.51 and 46.69 to $71.78 \mathrm{mg} \mathrm{kg}^{-1}$, respectively. Bioaccumulation coefficients of $\mathrm{Pb}$ in leaf, stem and root of Indian spinach were in the ranges of 0.63-1.94, 0.82-2.21 and 0.37-1.09, respectively.
\end{abstract}

Keywords: Lead (Pb), Concentration, Indian spinach, Leaf, Stem, Root.

\section{INTRODUCTION}

The uptake of toxic heavy metals from contaminated soils by plants is a prominent path for such elements to enter the food chain and finally be ingested by humans. Lead is ubiquitous and potentially hazardous contaminant in the biosphere (Zaman and Zereen 1998). Lead is not an essential element for crop plants. However, there are circumstantial evidences indicating that various plant species have the ability to absorb $\mathrm{Pb}$ by roots and translocate $\mathrm{Pb}$ from the roots to the shoots (Huang and Cunningham 1996, Hong et al. 2008). Lead is the most important pollutants with regard to its human-health effects via food chain contamination, as it is taken up and translocated to different plant parts where it can reach concentrations that become toxic to humans and animals (Huang and Cunningham 1996, Hong et al. 2008). Lead poisoning in humans causes severe

* Corresponding author 
damage in the kidneys, liver, brain, reproductive system, and central nervous system and sometimes causes death (Wildlife News 2000). The United States Environmental Protection Agency (USEPA) considers $\mathrm{Pb}$ as the second most important hazardous substance (Chen et al. 2003). According to Joint FAO/WHO Food Standards Programme (2002), the maximum level of $\mathrm{Pb}$ in grain crops is 0.2 $\mathrm{mg} \mathrm{kg}^{-1}$. Therefore, minimizing the intake of $\mathrm{Pb}$ from food is an important health issue. For ecological safety and human health, $\mathrm{Pb}$ uptake by food crops needs to be understood in order to limit its accumulation in the food chain. The well recognized sources of $\mathrm{Pb}$ in soil include vehicle exhausts, mining and smelting activities, sewage sludge and manure usage in agriculture (Alloway 1995). Korcak and Fanning (1985) found a positive relationship between the concentration of $\mathrm{Pb}$ in the soil and that in the plant. Heavy metal (especially $\mathrm{Cd}$ and $\mathrm{Pb}$ ) pollution in agricultural soils of Chittagong increased because of disposal of municipal and industrial solid and liquid wastes to the soil (Kibria 2008). In this background, the present study has been designed to investigate the effects of $\mathrm{Pb}$ on growth and accumulation of $\mathrm{Pb}$ in Indian spinach (Basella rubra L.).

\section{MATERIALS AND METHODS}

\section{Pot experiment}

Soils of three different textures namely clay loam, sandy clay loam and sandy loam were collected from (1) agricultural field located near new Science Faculty Building of Chittagong University, (2) ) agricultural field near Shahid Minar of Chittagong University, and (3) Syed Para at Hathazari Upazilla under Chittagong district from a depth of $0-15 \mathrm{~cm}$ on the basis of composite sampling method. Soil samples were air dried and larger and massive aggregates were broken down by gentle crushing with wooden pluck. Dry roots, grasses and other particulate materials were discarded from the soils and processed for pot experiment. A portion of the soils passed through $2 \mathrm{~mm}$ sieve was preserved for laboratory analyses. Characteristics of the soils are presented in Table 1.

Particle size distribution was determined by hydrometer method of Day (1965) and organic carbon (wet -oxidation method) and cation exchange capacity of the soils by the method of Jackson (1973). Soil pH was measured by glass electrode $\mathrm{pH}$ meter using soil: water ratio of 1:2.5. Total nitrogen was determined by Kjeldahl method as described by Jackson (1973). Soil samples were digested with a mixture of $\mathrm{HNO}_{3}$ and $\mathrm{HCl}$ at the ratio of 1:3 (Jackson 1973) for determination of total $\mathrm{P}, \mathrm{K}, \mathrm{Fe}, \mathrm{Mn}, \mathrm{Zn}, \mathrm{Cd}$ and $\mathrm{Pb}$. Phosphorus was determined by vanadomolybdophosphoric yellow color method in nitric acid system according to Jackson (1973). 
EFFECT OF APPLIED LEAD ON INDIAN SPINACH

TABLE 1 : PROPERTIES OF THE SOILS USED IN POT EXPERIMENT.

\begin{tabular}{lccc}
\hline Properties & Clay Loam Soil & Sandy Clay Loam Soil & Sandy Loam Soil \\
\hline Sand $(\%)$ & 30 & 57 & 63 \\
Silt $(\%)$ & 38 & 20 & 20 \\
Clay $(\%)$ & 32 & 23 & 17 \\
pH $\left(1: 2.5 \mathrm{H}_{2} \mathrm{O}\right)$ & 5.4 & 5.5 & 5.1 \\
Organic carbon $(\%)$ & 0.97 & 0.83 & 0.61 \\
CEC $\left(\mathrm{cmolkg}^{-1}\right.$ soil) & 7.86 & 6.93 & 6.43 \\
Total $\mathrm{N}(\%)$ & 0.15 & 0.09 & 0.04 \\
Total P $(\%)$ & 0.023 & 0.029 & 0.020 \\
Total $\mathrm{K}(\%)$ & 0.36 & 0.24 & 0.26 \\
Total $(\mathrm{Fe} \%)$ & 1.574 & 0.736 & 1.472 \\
Total Cd $\left(\mathrm{mg} \mathrm{kg}^{-1}\right)$ & 0.07 & $\mathrm{bdl} *$ & $\mathrm{bdl}$ \\
Total $\mathrm{Pb}\left(\mathrm{mg} \mathrm{kg}^{-1}\right)$ & 11.2 & 7.8 & 9.6 \\
Total $\mathrm{Zn}\left(\mathrm{mg} \mathrm{kg}^{-1}\right)$ & 108.7 & 58.96 & 55.02 \\
Total Mn $\left(\mathrm{mg} \mathrm{kg}^{-1}\right)$ & 185.06 & 190.20 & 86.90 \\
\hline
\end{tabular}

bdl= below detection limit $\left(<0.002 \mathrm{mg} \mathrm{kg}^{-1}\right)$

Potassium was determined by flame photometer and $\mathrm{Fe}, \mathrm{Mn}, \mathrm{Zn}, \mathrm{Cd}$ and $\mathrm{Pb}$ were determined by atomic absorption spectrophotometer (Varian spectra AA220).

A total number of 54 pots having diameter and depth 28 and $25 \mathrm{~cm}$, respectively were used. Eight kilograms soils were placed in each earthen pot. The fertilizer doses of N, P, K and S (99 kg N, $18 \mathrm{~kg} \mathrm{P}, 60 \mathrm{~kg} \mathrm{~K}$ and $18 \mathrm{~kg} \mathrm{~S} \mathrm{ha}^{-1}$ ) were applied from Urea, TSP, MP and zinc sulfate, respectively. According to Bangladesh Agricultural Research Council (2005) recommendation, half $\mathrm{N}$ and $\mathrm{K}$, and whole of $\mathrm{P}$ and $\mathrm{S}$ were applied during soil preparation. Five healthy and uniform seeds of Indian spinach were sown at equal distance in each pot. After two weeks of seedling emergence, one seedling was kept in each pot and different levels of $\mathrm{Pb}\left(0,10,20,30,40\right.$ and $50 \mathrm{mg} \mathrm{Pb} \mathrm{kg}^{-1}$ soil) were applied in solution form as lead nitrate $\left[\mathrm{Pb}\left(\mathrm{NO}_{3}\right)_{2}\right]$. Care was taken to keep uniform seedlings in the pots. Each treatment was replicated thrice and the pots were arranged in randomized block design. Remaining $\mathrm{N}$ and $\mathrm{K}$ were applied in two equal installments after 2 and 4 weeks of seedling emergence. Water was applied regularly in the pots to maintain the field capacity of the soils. Plants were harvested after five weeks of $\mathrm{Pb}$ application. Leaf, stem and roots were separately 
KIBRIA ET AL.

collected. Oven dry $\left(65^{\circ} \mathrm{C}\right.$ to constant weight $)$ weights of leaf stem and roots were recorded.

\section{Plant analysis}

Oven dried $\left(65^{\circ} \mathrm{C}\right.$ to constant weight) and ground plant samples were digested with ternary acid $\left(\mathrm{HNO}_{3}, \mathrm{H}_{2} \mathrm{SO}_{4}\right.$ and $\mathrm{HClO}_{4}$ mixture at ratio of 5:1:2) (Jackson 1973). The concentrations of $\mathrm{Cd}$ in the digested solution were measured by atomic absorption spectrophotometer (Varian Spectra AA 220).

\section{Data analysis}

The significance of differences between the means of the treatments was evaluated by one way analysis of variance followed by Duncan's Multiple Range Test at the significance level of 5\%. Pearson's correlation coefficient was estimated to test the relations between metal concentrations in plant tissues and metal content in soils.

\section{RESULTS AND DISCUSSION}

\section{Effects of Pb on Growth of Indian Spinach}

The growth response of Indian spinach after five weeks of $\mathrm{Pb}$ exposure in pot experiment is presented in Figure 1.

Dry weight of leaf, stem and root were in the ranges from 1.95 to $6.54,2.00$ to 3.48 and 0.36 to $1.32 \mathrm{~g} \mathrm{pot}^{-1}$ respectively. Exposure of Indian spinach to $\mathrm{Pb}$ in the range of $40-50 \mathrm{mg} \mathrm{Pb} \mathrm{kg}{ }^{-1}$ soil considerably reduced leaf dry weight in all the three soils. Root was affected by $40-50 \mathrm{mg} \mathrm{Pb} \mathrm{kg}^{-1}$ soil in sandy loam and sandy clay soil and only at $50 \mathrm{mg} \mathrm{Pb} \mathrm{kg}^{-1}$ soil in clay loam soil. Lead application did not cause any significant reduction in stem dry weight. The lowest dry weight biomass of leaf, stem and root were found at the highest rate of $\mathrm{Pb}$ application in this study except for stem in sandy loam soil. At the highest dose of $\mathrm{Pb}$ ( $50 \mathrm{mg}$ $\mathrm{Pb} \mathrm{kg}^{-1}$ soil) leaf, stem and root dry weights of Indian spinach were reduced by 22-34, 11- 43 and 30-47\%, respectively from control in the soils used in the present study. Kopittke et al. (2007) reported that relative fresh mass of cowpea (Vigna unguiculata) was reduced by $10 \%$ at a $\mathrm{Pb}^{2+}$ activity of $0.2 \mu \mathrm{M}$ for the shoots and at a $\mathrm{Pb}^{2+}$ activity of $0.06 \mu \mathrm{M}$ for the roots. A decrease of dry weight of two sunflower varieties cultivated in a hydrophonic system spiked with $\mathrm{Pb}$ at 7.5 and $10 \mu \mathrm{M}$ was observed by Nehnevajova (2005). Kosobrukhov et al. (2004) also reported a considerable decrease in dry weights of different plant parts under $\mathrm{Pb}$ treatments. 
EFFECT OF APPLIED LEAD ON INDIAN SPINACH
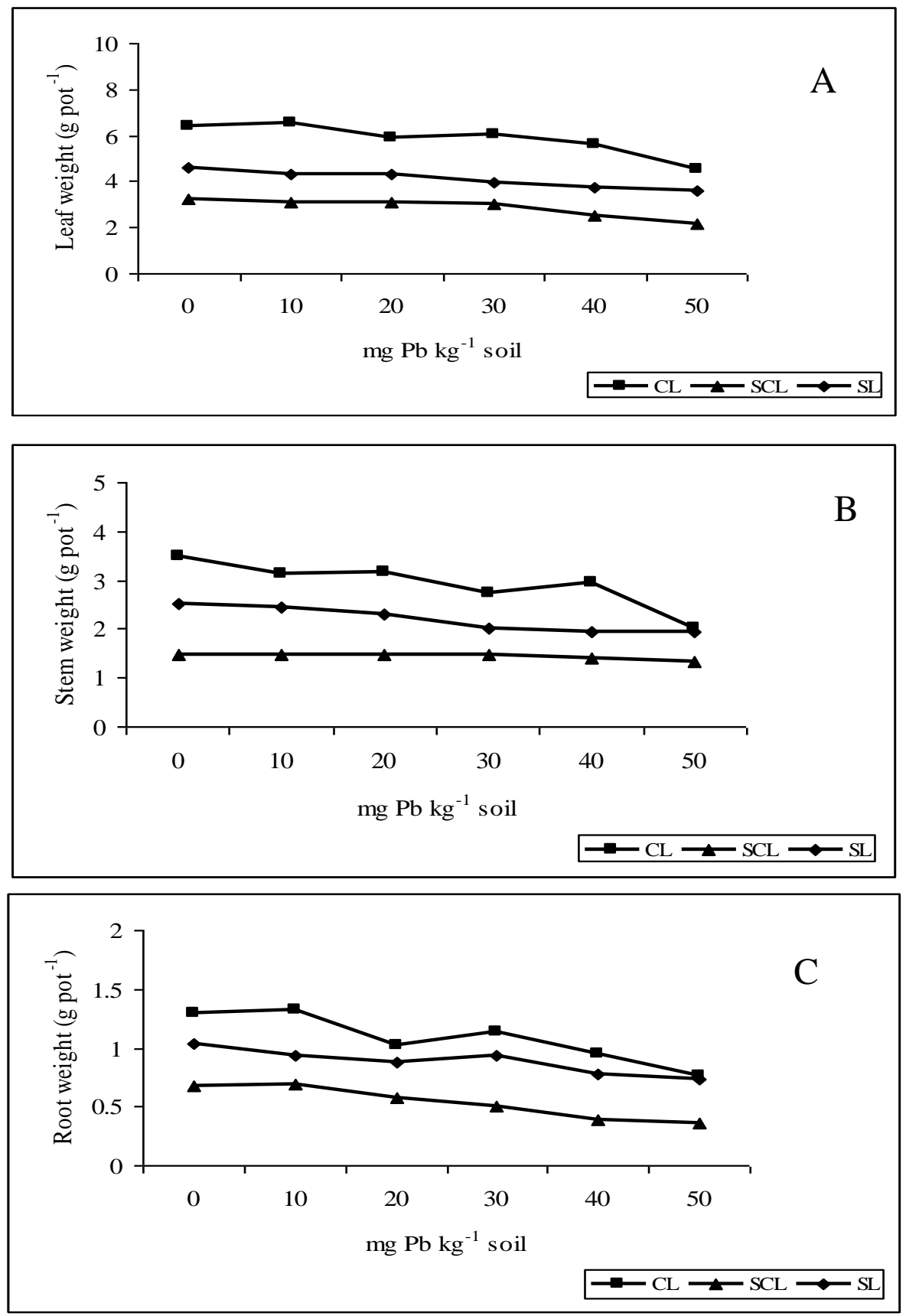

FIGURE 1 : EFFECTS OF LEAD ON LEAF (A), STEM (B) AND ROOT (C) WEIGHTS OF INDIAN SPINACH (CL-CLAY LOAM SOIL, SCL- SANDY CLAY LOAM SOIL AND SLSANDY LOAM SOIL) 


\section{Concentration of $\mathrm{Pb}$ in Indian Spinach}

Lead application in all the three soils affected $\mathrm{Pb}$ concentration in different plant parts of Indian spinach (Figure 2). Lead concentration in leaf, stem and root generally increased with increasing rate of $\mathrm{Pb}$ application. However, in clay loam soil, $\mathrm{Pb}$ application above 30 and $20 \mathrm{mg} \mathrm{Pb} \mathrm{kg}{ }^{-1}$ soil did not further increase significantly $\mathrm{Pb}$ concentration in leaf and stem respectively. This corroborates with the findings of Nehnevajova (2005) who reported that the increasing external concentration of $\mathrm{Pb}$ from 5 to $7.5 \mu \mathrm{M}$ significantly increased $\mathrm{Pb}$ concentration in shoot of sunflower in a hydrophonic culture. But a higher external $\mathrm{Pb}$ concentration $(10 \mu \mathrm{M})$ did not cause a further increase of shoot $\mathrm{Pb}$ accumulation.

Lead application at $50 \mathrm{mg} \mathrm{kg}^{-1}$ soil increased $\mathrm{Pb}$ concentration in leaf, stem and root about 6,8 and 6 fold than that with no $\mathrm{Pb}$ application in clay loam soil in the present study. Lead concentration in leaf, stem and root increased by 9,13 and 6 fold in sandy clay loam soil and 11, 10 and 9 fold in sandy loam soil, respectively with $50 \mathrm{mg} \mathrm{Pb} \mathrm{kg}{ }^{-1}$ soil application than that of the control. The highest $\mathrm{Pb}$ concentration in leaf, stem and root in the present study obtained at 50 $\mathrm{mg} \mathrm{Pb} \mathrm{kg}{ }^{-1}$ soil treatment were in the ranges 49.28 to $65.40,57.72$ to 77.51 and 46.69 to $71.78 \mathrm{mg} \mathrm{kg}^{-1}$, respectively. At lower applications of $\mathrm{Pb}$ in soil, $\mathrm{Pb}$ concentrations were higher in leaf and stem than in root indicating larger transfer of this metal from root to stem and leaf. On the contrary, it was reported that $\mathrm{Pb}$ accumulation in roots is significantly higher than that in shoots, possibly because of the low $\mathrm{Pb}$ translocation from root to shoots Lead concentrations in cowpea roots were 10-50 times higher than in shoots (Kopittke et al. 2007). Research with other species also revealed similarly large differences, for example, 15 times higher in maize (Malkowski et al. 2002), 100-300 times higher in Norway spruce (Goldbold and Kettner 1991).

The percentage of $\mathrm{Pb}$ translocated in the leaves and stem of the total accumulated $\mathrm{Pb}$ in Indian spinach were from 57.02 to 60.57 and 29.10 to 39.75 respectively in clay loam soil (Table 2). The corresponding values were 48.59 56.58 and $26.49-43.38 \%$ in sandy clay loam soil; and 55.66- 69.37 and $21.37-28.40 \%$ in sandy loam soil, respectively. The translocation of accumulated $\mathrm{Pb}$ in leaves was more pronounced in sandy loam soil in comparison to other two soils. Differences between tolerant and non tolerant plants in the distribution of metals over root and shoot have been frequently reported (Ernst et al. 1992). Metal tolerant plants showing a diminished accumulation of the respective metal in shoot have been found to accumulate higher amounts in root compared to non-tolerant ones of the same species (Baker 1987, Das et al. 1997). 
EFFECT OF APPLIED LEAD ON INDIAN SPINACH
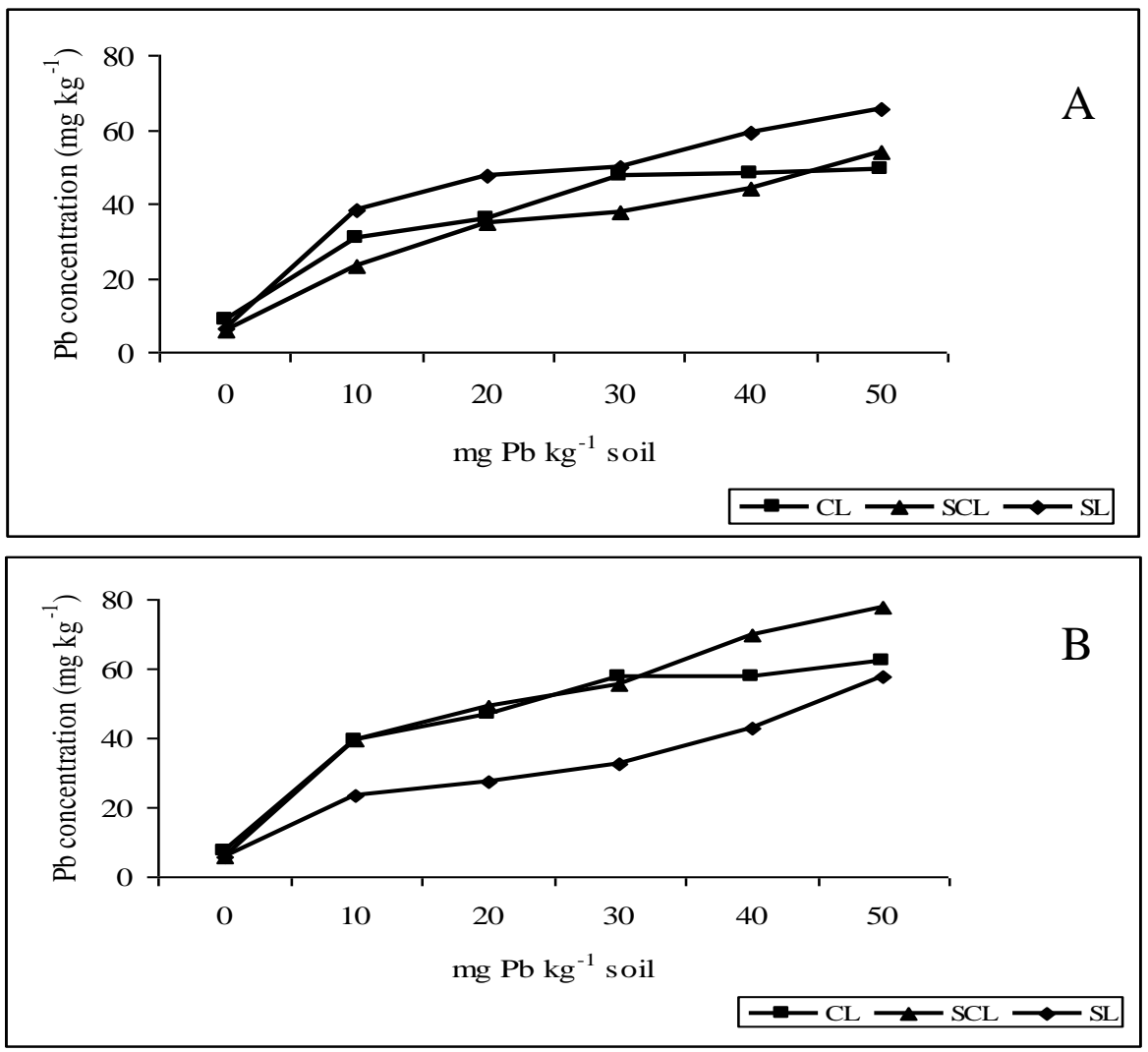

(Cunningham et al., 1995).

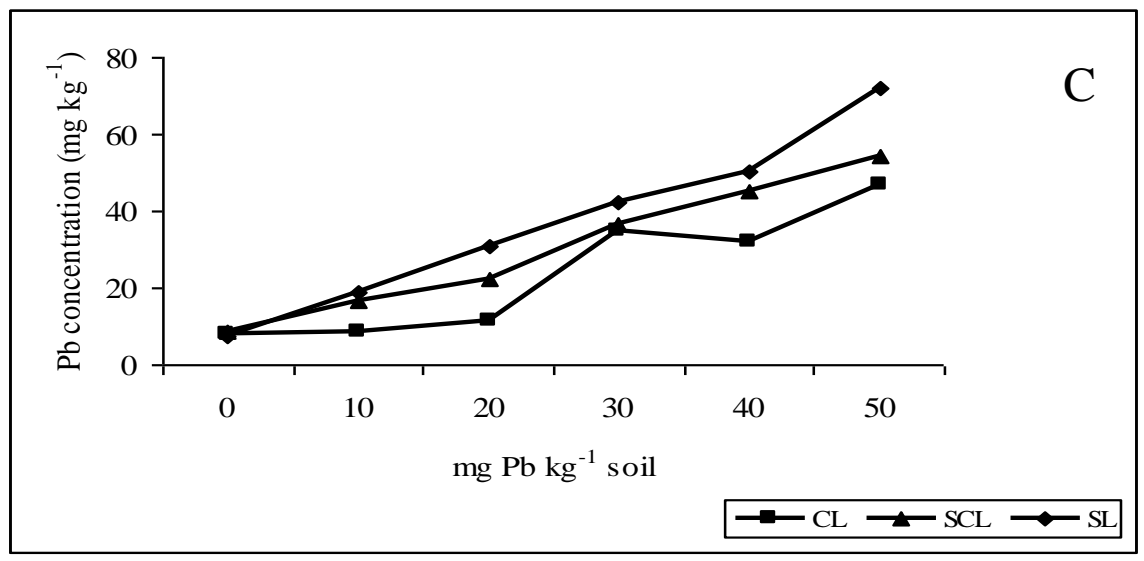

FIGURE 2 : EFFECTS OF LEAD ON CONCENTRATION OF Pb IN LEAF (A), STEM (B) AND ROOT (C) OF INDIAN SPINACH (CL-CLAY LOAM SOIL, SCL- SANDY CLAY LOAM SOIL AND SL- SANDY LOAM SOIL). 
KIBRIA $E T A L$.

TABLE 2 : DISTRIBUTION OF Pb (\% OF TOTAL ACCUMULATION) IN DIFFERENT PLANT PARTS OF INDIAN SPINACH GROWN N Pb SPIKED SOILS.

\begin{tabular}{|c|c|c|c|c|c|c|c|c|c|}
\hline \multirow{2}{*}{$\begin{array}{l}\text { Treatment } \\
(\mathrm{mg} \mathrm{Pb} \\
\mathrm{kg}^{-1} \text { soil) }\end{array}$} & \multicolumn{3}{|c|}{ Clay Loam Soil } & \multicolumn{3}{|c|}{ Sandy Clay Loam Soil } & \multicolumn{3}{|c|}{ Sandy loam Soil } \\
\hline & Leaf & Stem & Root & Leaf & Stem & Root & Leaf & Stem & Root \\
\hline 0 & $59.83 \mathrm{a}$ & $29.10 \mathrm{a}$ & $11.07 \mathrm{a}$ & $56.58 \mathrm{a}$ & $26.49 \mathrm{a}$ & $16.93 \mathrm{a}$ & $55.66 \mathrm{c}$ & $28.40 \mathrm{a}$ & $15.96 \mathrm{a}$ \\
\hline 10 & $60.57 \mathrm{a}$ & $35.95 \mathrm{a}$ & $3.48 \mathrm{c}$ & $50.50 \mathrm{a}$ & $41.33 \mathrm{a}$ & $8.17 \mathrm{~b}$ & $69.21 \mathrm{a}$ & $23.34 \mathrm{a}$ & $7.45 \mathrm{~d}$ \\
\hline 20 & $57.02 \mathrm{a}$ & $39.75 \mathrm{a}$ & $3.23 \mathrm{c}$ & $56.26 \mathrm{a}$ & $37.01 \mathrm{a}$ & $6.73 \mathrm{~b}$ & $69.37 \mathrm{a}$ & $21.37 \mathrm{a}$ & $9.25 \mathrm{~cd}$ \\
\hline 30 & $59.24 \mathrm{a}$ & $32.57 \mathrm{a}$ & $8.19 \mathrm{ab}$ & $52.84 \mathrm{a}$ & $38.68 \mathrm{a}$ & $8.48 \mathrm{~b}$ & $65.19 \mathrm{ab}$ & $21.56 \mathrm{a}$ & $13.25 \mathrm{ab}$ \\
\hline 40 & $57.88 \mathrm{a}$ & $35.55 \mathrm{a}$ & $6.57 \mathrm{~b}$ & $49.22 \mathrm{a}$ & $43.38 \mathrm{a}$ & $7.41 \mathrm{~b}$ & $64.31 \mathrm{ab}$ & $24.28 \mathrm{a}$ & $11.41 \mathrm{bc}$ \\
\hline 50 & 58.73 a & $31.87 \mathrm{a}$ & $9.40 \mathrm{ab}$ & 48.59 a & $42.47 \mathrm{a}$ & $8.94 \mathrm{~b}$ & $59.10 \mathrm{bc}$ & $27.79 \mathrm{a}$ & $13.11 \mathrm{ab}$ \\
\hline $\begin{array}{l}\text { Sig. of F } \\
\text { Value }(\mathrm{P})\end{array}$ & NS & NS & 0.001 & NS & NS & 0.001 & 0.01 & NS & 0.01 \\
\hline
\end{tabular}

Mean values in the column followed by the same letter (s) are not significantly different according to DMRT $(\mathrm{P} \leq 0.05)$.

Bioaccumulation coefficients of $\mathrm{Pb}$ in leaf, stem and root of Indian spinach were in the ranges of $0.63-1.94,0.60-2.21$ and $0.37-1.20$, respectively. The $\mathrm{Pb}$ bioaccumulation coefficient of 90 for corn shoot and 20 for ragweed shoots at an external solution $\mathrm{Pb}$ concentration of $20 \mu \mathrm{M}$ was reported by Huang and Cunningham (1996). Bioaccumulation coefficient of $\mathrm{Pb}$ in leaf and stem of Indian spinach gradually decreased, in general, with the increase of rate of $\mathrm{Pb}$ application in soil (Table 3). The root bioaccumulation coefficients of $\mathrm{Pb}$ did not show any trend of variation with the $\mathrm{Pb}$ application in clay loam and sandy clay loam soil. However, root $\mathrm{BC}$ of $\mathrm{Pb}$ in sandy loam soil decreased with the increase of $\mathrm{Pb}$ application up to $40 \mathrm{mg} \mathrm{kg}^{-1}$ soil. 
EFFECT OF APPLIED LEAD ON INDIAN SPINACH

TABLE 3 : BIOACCUMULATION COEFFICIENT OF LEAD IN DIFFERENT PLANT PARTS OF INDIAN SPINACH GROWN IN Pb SPIKED SOILS.

\begin{tabular}{|c|c|c|c|c|c|c|c|c|c|}
\hline \multirow{2}{*}{$\begin{array}{l}\text { Treatment } \\
(\mathrm{mg} \mathrm{Pb} \\
\mathrm{kg}^{-1} \text { soil) }\end{array}$} & \multicolumn{3}{|c|}{ Clay Loam Soil } & \multicolumn{3}{|c|}{ Sandy Clay Loam Soil } & \multicolumn{3}{|c|}{ Sandy loam Soil } \\
\hline & Leaf & Stem & Root & Leaf & Stem & Root & Leaf & Stem & Root \\
\hline 0 & $0.76 \mathrm{c}$ & $0.68 \mathrm{c}$ & $0.70 \mathrm{ab}$ & $0.75 \mathrm{c}$ & $0.77 \mathrm{~d}$ & $1.09 \mathrm{a}$ & $0.63 \mathrm{~d}$ & $0.60 \mathrm{c}$ & $0.79 \mathrm{a}$ \\
\hline 10 & $1.45 \mathrm{a}$ & $1.87 \mathrm{a}$ & $0.40 \mathrm{c}$ & $1.29 \mathrm{a}$ & $2.21 \mathrm{a}$ & $0.92 \mathrm{a}$ & $1.94 \mathrm{a}$ & $1.18 \mathrm{a}$ & $0.95 \mathrm{a}$ \\
\hline 20 & $1.15 \mathrm{~b}$ & $1.50 \mathrm{ab}$ & $0.37 \mathrm{c}$ & $1.25 \mathrm{a}$ & $1.76 \mathrm{~b}$ & $0.80 \mathrm{a}$ & $1.60 \mathrm{~b}$ & $0.93 a b$ & $1.04 \mathrm{a}$ \\
\hline 30 & $1.16 \mathrm{~b}$ & $1.41 \mathrm{abc}$ & $0.85 \mathrm{a}$ & $1.00 \mathrm{~b}$ & $1.47 \mathrm{bc}$ & $0.96 \mathrm{a}$ & $1.26 \mathrm{c}$ & $0.82 \mathrm{bc}$ & $1.07 \mathrm{a}$ \\
\hline 40 & $0.93 \mathrm{bc}$ & $1.12 \mathrm{bc}$ & $0.62 \mathrm{~b}$ & $0.92 \mathrm{~b}$ & $1.46 \mathrm{bc}$ & $0.94 \mathrm{a}$ & $1.19 \mathrm{c}$ & $0.86 \mathrm{bc}$ & $1.01 \mathrm{a}$ \\
\hline 50 & $0.81 \mathrm{c}$ & $1.02 \mathrm{bc}$ & $0.76 \mathrm{ab}$ & $0.94 \mathrm{~b}$ & $1.34 \mathrm{c}$ & $0.94 \mathrm{a}$ & $1.10 \mathrm{c}$ & $0.97 \mathrm{ab}$ & $1.20 \mathrm{a}$ \\
\hline Sig. of $F$ & 0.001 & 0.05 & 0.001 & 0.001 & 0.001 & NS & 0.001 & 0.001 & NS \\
\hline Value $(\mathrm{P})$ & & & & & & & & & \\
\hline
\end{tabular}

Mean values in the column followed by the same letter (s) are not significantly different according to DMRT $(\mathrm{P} \leq .05)$.

Extractable Pb in soils after harvest of Indian spinach

A small amount of background $\mathrm{Pb}\left(11.2,7.8\right.$ and $9.6 \mathrm{mg} \mathrm{kg}^{-1}$ in clay loam, sandy clay loam and sandy loam soil, respectively) was in the soils used for this experiment as mentioned in Table 1. In control soils, 5, 9 and $4 \%$ of the total $\mathrm{Pb}$ in clay loam, sandy clay loam and sandy loam soil respectively were estimated to be $0.1 \mathrm{M} \mathrm{HCl}$ extractable. In soils to which $\mathrm{Pb}$ was added, 22-31, 6-44 and $18-35 \%$ of the total metal in clay loam, sandy clay loam and sandy loam soil respectively were extractable (Table 4). Metals extracted with $0.1 \mathrm{M} \mathrm{HCl}$ are thought to represent the mobile fraction of metals and may reflect the bioavailability of metals (Kashem et al. 2007). 
KIBRIA $E T A L$

TABLE $4: 0.1 \mathrm{M}$ HCL EXTRACTABLE Pb IN SOILS AFTER HARVEST OF INDIAN SPINACH.

\begin{tabular}{cccc}
\hline Treatment & \multicolumn{3}{c}{ Extractable Pb $\left(\mathrm{mg} \mathrm{kg}^{-1}\right.$ of soil $)$} \\
\cline { 2 - 4 }$\left(\mathrm{mg} \mathrm{Pb} \mathrm{kg}^{-1}\right.$ soil $)$ & Clay Loam Soil & Sandy Clay Loam Soil & Sandy Loam Soil \\
\hline 00 & $0.53 \pm 0.11\left(5^{*}\right)$ & $0.75 \pm 0.21(9)$ & $0.34 \pm 0.06(4)$ \\
10 & $4.55 \pm 0.17(22)$ & $4.53 \pm 1.29(6)$ & $3.90 \pm 0.66(20)$ \\
20 & $9.12 \pm 1.10(29)$ & $10.36 \pm 0.79(37)$ & $5.28 \pm 0.83(18)$ \\
30 & $11.87 \pm 1.27(29)$ & $14.52 \pm 0.65(38)$ & $14.01 \pm 3.59(35)$ \\
40 & $15.19 \pm 1.74(30)$ & $20.87 \pm 1.58(44)$ & $13.96 \pm 1.77(28)$ \\
50 & $18.75 \pm 0.59(31)$ & $16.69 \pm 2.62(29)$ & $15.20 \pm 1.78(26)$ \\
\hline
\end{tabular}

* Percentage of total $\mathrm{Pb}$ extracted by $0.1 \mathrm{M} \mathrm{HCl}$ is given the parenthesis.

A highly positive correlation between $0.1 \mathrm{M} \mathrm{HCl}$ extractable $\mathrm{Pb}$ and concentrations of $\mathrm{Pb}$ in plant parts of Indian spinach was found in all the three soils (Table 5). Further, $\mathrm{Pb}$ concentrations in plant parts of Indian spinach were also highly correlated with total soil $\mathrm{Pb}$ added. This is in conformity with Kibria et al. (2007) who reported that radish showed a highly positive correlation between $\mathrm{Pb}$ applications in soils and $\mathrm{Pb}$ concentration in root and shoot.

TABLE 5 : CORRELATION COEFFICIENTS BETWEEN TOTAL Pb IN SOIL AND Pb CONCENTRATION IN PLANT AND BETWEEN 0.1 M HCL EXTRACTABLE Pb IN SOIL AND Pb CONCENTRATION IN PLANT PARTS OF INDIAN SPINACH.

\begin{tabular}{ccccc}
\hline Lead & Soil & Leaf & Stem & Root \\
\hline \multirow{2}{*}{ Total } & Clay Loam & $0.872^{* *}$ & $0.804^{* *}$ & $0.925^{* *}$ \\
& Sandy Clay Loam & $0.959 * *$ & $0.938^{* *}$ & $0.989^{* *}$ \\
& Sandy Loam & $0.892^{* *}$ & $0.938^{* *}$ & $0.956^{* *}$ \\
\hline \multirow{2}{*}{$0.1 \mathrm{M} \mathrm{HCl}$} & Clay Loam & $0.922^{* *}$ & $0.892^{*}$ & $0.919^{* *}$ \\
Extractable & Sandy Clay Loam & $0.912^{*}$ & $0.924 *$ & $0.923^{* *}$ \\
& Sandy Loam & $0.874 *$ & $0.893^{*}$ & $0.927 * *$ \\
\hline * and ** represent that correlation is significant at the 0.05 and 0.01 level, respectively.
\end{tabular}




\section{EFFECT OF APPLIED LEAD ON INDIAN SPINACH}

Lead application in all the tree soils significantly reduced leaf and root weight of Indian spinach. Lead concentration in leaf, stem and root of Indian spinach generally increased with increasing application of $\mathrm{Pb}$ in soil from that of the control. The translocation of accumulated $\mathrm{Pb}$ in leaves was more pronounced in sandy loam soil in comparison to other two soils. A highly positive correlation between $0.1 \mathrm{M} \mathrm{HCl}$ extractable $\mathrm{Pb}$ in soil and concentrations of $\mathrm{Pb}$ in plant parts of Indian spinach was found in all the three soils

\section{REFERENCES}

ALLOWAY, B. J. 1995. Heavy Metals in Soils. $2^{\text {nd }}$ Ed. Blackie Academic \& Professional, An imprint of Chapman \&Hall, U K.

BAKER, A.J.M. 1987. Metal tolerance. New Phytology 106: 93-111.

BANGLADESH AGRICULTURAL RESEARCH COUNCIL (BARC ). 2005. Fertilizer Recommendation Guide. BARC Soils Publication No. 45.

CHEN, M., MA, L.Q., SINGH, S.P., CAO, R.X. AND MELAMED, R. 2003. Field demonstration of in situ immobilization of soil $\mathrm{Pb}$ using $\mathrm{P}$ amendments. Advan. Environ. Res. 8: 93-102.

CUNNINGHAM, S.D., BERTI, W.R. AND HUANG, J.W. 1995. Remediation of contaminated soils and sludges by green plants. In: Bioremediation of Inorganic. R.E. Hinchee, J.L. Means, D.R. Burris (eds.)., Columbus, Ohio, Battelle Press. pp. 33-54.

DAS, P., SAMANTARAY, S. AND ROUT, G. 1997. Studies on cadmium toxicity in plants: A review. Environ. Pollut. 98: 29-36.

DAY, P. R. 1965. Particle fractionation and particle size analysis. In: Methods of Soil Analysis .C.A. Black (ed.). Part I. Agronomy Monograph, Academic Press, New York.. pp. 545-567.

ERNST, W.H.O., SCHAT, H. AND VERKLEIJ, J.A.C. 1992. Metal tolerance in plants. Acta Botanica. Neerl. 41: 229-248.

GOLDBOLD, D.L. AND KETTNER, C. 1991. Lead influences root growth and mineral nutrition of Picea abies seedlings. J. Plant Physiol. 139: 95-99

HONG,C. L., JIA, Y.B., YANG, X.E., HE Z.L. AND STOFFELLA, P.J. 2008. Assessing lead thresholds for phytotoxicity and potential dietary toxicity in selected vegetable crops. Bullet. Environ. Contam. Toxicol. 80:356-361.

HUANG, J.W. AND CUNNINGHAM, S.D.1996. Lead phytoextraction: species variation in lead uptake and translocation. New Phytology 134: 75-84.

JOINT FAO/WHO FOOD STANDARDS PROGRAMME. 2002. Distribution of the report of the thirty-fourth session of the codex committee on food additives and contaminants (Alinorm03/12) Rome. 
JACKSON, M. L. 1973. Soil Chemical Analysis. Prentice Hall of India Private Limited, New Delhi, India. 498pp.

KASHEM, M.A., SINGH, B.R., KONDO, T., HUQ S.M.I. AND KAWAI, S. 2007. Comparison of extractability of cadmium, copper, lead and zinc with sequential extraction in contaminated and non-contaminated soils. Int. J. Environ. Sci.Technol. 4 (2): 169-176.

KIBRIA, M.G., OSMAN, K.T. AND AHMED, M.J. 2007. Cadmium and lead uptake by radish (Raphanus sativus L.) grown in three different textured soils. Soil Environ. 26 (2):106-114.

KIBRIA, M.G. 2008. Dynamics of cadmium and lead in some soils of Chittagong and their influx in some edible crops. Ph.D. Thesis. University of Chittagong, Bangladesh.

KOPITTKE, P.M., ASHER, C.J., KOPITTKE, R.A. AND MENZIES, N.W. 2007. Toxic effects of $\mathrm{Pb}^{2+}$ on growth of cowpea (Vigna unguiculata). Environ. Pollut. 150: 280-287.

KORCAK, R. F. AND FANNING, D. S. 1985. Availability of applied metals as a function of type of soil material and metal source. Soil Science 140: 23-34.

KOSOBRUKHOV, A., KNYAZEVA, I. AND MUDRIK, V. 2004. Plantago major plants responses to increase content of lead in soil: growth and photosynthesis. Plant Growth Regul. 42: 145-151.

MALKOWSKI, E., KITA, A., GALAS, W., KAREZ, W. AND KUPERBURG, J.M. 2002. Lead distribution in corn seedlings (Zea mays L.) and its effect on growth and the concentrations of potassium and calcium. Plant Growth Regul. 37: 69-76.

NEHNEVAJOVA, E. 2005. Non-GMO approach for the improvement of heavy metal accumulation and extraction of high yielding crop species for efficient phytoextraction of contaminated soil. Ph. D. Thesis. School of Architecture, Civil and Environmental Engineering Swiss Federal Institute of Technology Lausanne (EPFL).

ZAMAN, M. S. AND ZEREEN, F. 1998. Growth responses of radish plants to soil cadmium and lead contamination. Bullet. Environ. Contam. Toxicol. 61: 44-50.

WILDLIFE NEWS. 2000. Researcher work to reduce lead poisoning of children in Chicago's West Town. Chicago. USA.

Manuscript received on 26.7.11; Accepted on 29.9.11

The Chittagong University Journal of Biological Sciences, Vol. 5 (1 \& 2). Page No:113-124 